Suzana M. Savićl ${ }^{3}$,

Gordana R. Tešanović, ${ }^{1,3}$,

Kosana D. Stanetić, ${ }^{1,3}$,

Snježana M. Popović-Pejičićc,

'Primary Health Center Banja Luka,

${ }^{2}$ University Clinical Center Banja Luka,

${ }^{3}$ Faculty of Medicine, University of Banja Luka,

Republic of Srpska, Bosnia and Herzegovina

\section{The impact of lifestyle change on the parameters of glycemic control in type 2 diabetes}

\section{Abstract}

Introduction: Changes in lifestyle can significantly affect the management of good glycemic control and target values of blood pressure and lipids.

Objective: To determine the achievement of target values of glycated hemoglobin $\left(\mathrm{HbA}_{1} \mathrm{c}\right)$, blood pressure and lipids, in participants with type 2 diabetes, who used a proper diet and controlled physical activity.

Method: The study was a prospective study, conducted on participants with type 2 diabetes, from 01 October 2012 until 31 October 2013, at the Primary Health Center Banja Luka, by 60 family medicine teams. At the beginning of the study, all participants had individual counseling on lifestyle changes, eating habits, and regulation of body weight.

Results: The study included 591 participants with the type 2 diabetes. At the beginning of the study, $49.92 \%$ of participants adhered to the proper diet, and at the end $76.65 \%$ of them $(\mathrm{p}<0.001)$. Targeted value of $\mathrm{HbA}_{1} \mathrm{c} \leq 6.5 \%$ was registered in $61.70 \%$ participants at the beginning of the study and at the end of the study in $86.62 \%$ participants $(\mathrm{p}<0.001)$; the target value of blood pressure $(\leq 130 / 80 \mathrm{mmHg})$ was registered in $56.21 \%$ at the beginning, and at the end in $79.91 \%(\mathrm{p}<0.002)$. Targeted value of total cholesterol was registered in $59.61 \%$ at the beginning of the study, and at the end of the study in $81.91 \%$ subjects $(\mathrm{p}<0.003)$.

Conclusion: In patients with type 2 diabetes individual counseling about lifestyle changes helps to attain optimal values of $\mathrm{HbA}_{1} \mathrm{c}$, blood pressure, and serum lipid levels. 


\section{Introduction}

Diabetes mellitus is a multifactorial disease, developing in genetically sensitive individuals under the influence of external factors ${ }^{1}$. Therefore, beside genetic factors, equally important are environmental factors, and the way of life. Risk factors for the occurrence of the disease can be divided into two groups: unmodifiable (age, sex, genetic factors) and modifiable - environmental factors that can be potentially prevented ${ }^{1,2}$. The non-genetic risk factors have a significant position in the emergence of type 2 diabetes, especially in people over 45 years of age. They are related to obesity (duration, degree of obesity and body fat distribution), a diet rich in fat and saturated fat, and insulin resistance ${ }^{1-4}$. The American Association of Diabetes Educators lists seven important factors: physical activity, healthy diet, regular medication, blood glucose monitoring, self-care regarding to the problems of diabetes, reduction of the risk of acute and chronic complications and psychosocial aspects of living with diabetes, which provide a useful framework for assessing, monitoring and certification of diabetes. The differences in the behavior of patients, health beliefs and different cultures, and the patient's emotional response to the disease itself, may play an important role in the understanding, commitment and self-control of type 2 diabetes $^{5}$. A meta-analysis of nine studies involving obese patients with type 2 diabetes indicated that a loss of $9.6 \%$, of body weight in the six weeks period, resulted in reduction of glycemic load by $50 \%$ from baseline'. In 'The Heart Outcomes Prevention Evaluation Study' was found that an increase in obesity in patients with type 2 diabetes, particularly abdominal, increased the risk of myocardial infarction by $23 \%$, risk of heart failure by $35 \%$, and general mortality by $17 \%$. Data released by Keymel and associates in 2011 indicate that diabetes, unless strictly controlled, leads to functional and structural vascular changes, accelerates the process of atherosclerosis and the onset of cardiovascular disease ${ }^{8}$. Meta-analysis by Boulé and associates indicated that the structured application of physical activity over eight weeks led to a reduction in $\mathrm{HbA}_{1} \mathrm{c}$ from $8.31 \%$ to $7.65 \%$, and significantly contributes to better glycemic control 9 . Regular physical activity of uniform intensity and duration, increases insulin sensitivity, leads to better metabolic regulation of glycemia, glycated hemoglobin and lipid profile, reduces other risks of cardiovascular diseases (elevated blood pressure, obesity, blood clotting disorders) and the onset of late complications of diabetes, and positively affects the mental state of people with diabetes ${ }^{10}$. Based on the available literature data, it has been established that diabetic patients need to conduct structured exercises that are the cornerstone for achieving good glycemic control and reducing cardiovascular risk. Patients should be stimulated to participate in specially adapted intervention programs, and more attention should be paid to the cardiovascular and osteo- muscular system ${ }^{11}$. The recommendations of the American Diabetes Association on Physical Activity, published in Diabetes Care 2016, argue that patients with diabetes should reduce the sedentary lifestyle, e.g. they should not spend more than 90 minutes in a sitting position (computer work, watching $\mathrm{TV}$, etc. $)^{12}$, which is in line with the advices we provided during our study to our participants. Based on the data obtained by searching the databases: MEDLINE, COCHRANE-CENTRAL, EMBASS, CLINICALTRIALS. GOV, LILACS and SPORTDISCUS DATABASES, from January 1980 to February 2011 (synthesis of 4,191 articles with 8,538 subjects with diabetes), structured trainings/ aerobic exercises (in 23 studies) were associated with a decrease in glycated hemoglobin level. This effect was not observed in subjects who did not perform physical activity. Structured exercise for more than 150 minutes per week was associated with a decrease in glycated hemoglobin by $0.89 \%$, while exercise of less than 150 minutes per week was associated with a decrease in glycated hemoglobin by $0.36 \%$. It has been proven that physical activity advices combined with dietary nutrition have been associated with lowering the value of glycated hemoglobin ${ }^{13}$, which was highlighted in our research.

Considering that in the Republic of Srpska similar researches were not conducted, the goal of our study was to determine the achievement of target values for glycated hemoglobin $(\mathrm{HbA} 1 \mathrm{c})$, blood pressure and lipid levels in subjects with type 2 diabetes, which used the correct diet and controlled physical activity.

\section{Objective}

The aim of this study was to determine the achievement of target values of glycated hemoglobin $\left(\mathrm{HbA}_{1} \mathrm{c}\right)$, blood pressure and lipids, in participants with type 2 diabetes, who used a proper diet and controlled physical activity.

\section{Method}

The study is a prospective-observational, descriptive exploratory study conducted in 591 patients with type 2 diabetes mellitus in the Health Center Banja Luka. The research was performed in the period from 01 October 2012 to 31 October 2013, with the written consent of the Director and the Ethics Committee of the institution. The study included patients of both sexes, more than 30 years old, who had type 2 diabetes more than two years. All patients with significant physical or mental health disorders were excluded from the study. The nurses/technicians, according to electronic records, contacted participants by telephone and scheduled appointments for medical examination. Family medicine teams involved in research organized education on proper 
nutrition, as recommended by the guide for diabetes mellitus from $2010^{14}$ and the recommendations of the ADA/EASD ${ }^{15-19}$ for all participants. Education was organized during the last week in October 2012 in the form of small group work in family medicine, lasting 45 minutes. Each team educated 10 subjects with type 2 diabetes about the importance of proper and individually customized diet (caloric index of nutritients, the number of daily meals and the recommended daily intake of salt), adequate physical activity of aerobic type (walking, running, cycling, swimming $)^{14,17,19,20}$, and identification and techniques for giving up smoking ${ }^{14,17,20-22}$. Family medicine teams continuously, every three months provided support to the subjects and promoted a healthy lifestyle as an integral part of modern treatment guidelines. Necessary biochemical blood tests were performed in Department for laboratory and biochemical diagnosis of Health Center Banja Luka.

\section{Statistical data processing}

Data obtained in the research were entered in the Excel database, and analyzed using IBM SPSS Statistics 19.0 program. In the processing of data, the following statistical methods were used: Pearson's $\chi^{2}$ test contingency, Student's ttest, Wilcoxon's W test, Mann-Whitney U test, KolmogorovSmirnov test for normal distribution. In all used statistical methods level of significance was at $\mathrm{p}<0.05$ and $\mathrm{p}<0.001$.

\section{Results}

The study included 591 patients with type 2 diabetes, 318 (52.45\%) males and $281(47.55 \%)$ females, from three age groups: younger than $55(22.64 \%), 55$ to 64 years old $(40.27 \%)$ and older than 65 years $(37.06 \%)$. The decrease in $\mathrm{HbA}_{1} \mathrm{c}$ level, according to the gender structure of subjects during the 13 months study was statistically significant $\left(\mathrm{P} \chi^{2}\right.$ : $\mathrm{p}<0.001$ ) (Table 1).

Table 1. Presentation of participants by gender and age

Табела 1. Састав испитаника према полу и старости

\begin{tabular}{|c|c|c|c|c|c|c|}
\hline Variable & \multicolumn{3}{|l|}{$\mathbf{N}$} & \multicolumn{3}{|l|}{$\%$} \\
\hline \multicolumn{7}{|l|}{ Gender } \\
\hline Male & \multicolumn{3}{|l|}{318} & \multicolumn{3}{|c|}{52.45} \\
\hline Female & \multicolumn{3}{|l|}{281} & \multicolumn{3}{|c|}{47.55} \\
\hline \multicolumn{7}{|l|}{ Age/years } \\
\hline$<55$ & \multicolumn{3}{|l|}{134} & \multicolumn{2}{|c|}{22.64} & \\
\hline $55-64$ & \multicolumn{3}{|l|}{238} & \multicolumn{2}{|c|}{40.27} & \\
\hline$>65$ & \multicolumn{3}{|l|}{219} & \multicolumn{2}{|c|}{37.06} & \\
\hline $\mathrm{HbA}_{1} \mathrm{c} /$ October 2012. & \multicolumn{3}{|c|}{ Male } & \multicolumn{2}{|c|}{ Female } & \\
\hline$<6.50 \%$ & $\begin{array}{r}\mathrm{n} \\
56\end{array}$ & $\begin{array}{l}\% \\
18.06\end{array}$ & \multirow{4}{*}{$\begin{array}{l}\mathrm{P} \chi^{2}: \\
\mathrm{p}<0.001\end{array}$} & $\begin{array}{l}\mathrm{n} \\
38\end{array}$ & $\begin{array}{l}\% \\
13.52\end{array}$ & \multirow[t]{5}{*}{$\mathrm{P} \chi^{2}: \mathrm{p}<0.001$} \\
\hline $6.51-7.00 \%$ & 69 & 22.26 & & 53 & 18.86 & \\
\hline $7.01-8.50 \%$ & 113 & 36.45 & & 110 & 39.15 & \\
\hline$>8.50 \%$ & 72 & 23.23 & & 80 & 28.47 & \\
\hline \multicolumn{6}{|l|}{$\mathrm{HbA}_{1} \mathrm{c} /$ October 2013.} & \\
\hline$<6.50 \%$ & 170 & 54.84 & \multirow{4}{*}{$\begin{array}{l}\mathrm{P} \chi^{2}: \\
\mathrm{p}<0.001\end{array}$} & 129 & 45.91 & \multirow[t]{4}{*}{$\mathrm{P} \chi^{2}: \mathrm{p}<0.001$} \\
\hline $6.51-7.00 \%$ & 79 & 25.48 & & 69 & 24.56 & \\
\hline $7.01-8.50 \%$ & 60 & 19.35 & & 79 & 28.11 & \\
\hline$>8.50 \%$ & 1 & 0.32 & & 4 & 1.42 & \\
\hline
\end{tabular}


According to body mass index, the highest percentage of participants (above $45 \%$ ) was overweight; more than $22 \%$ of subjects had the obesity of I degree, while normal nutrition accounted for about $19 \%$ of participants. BMI changes during the 13-months follow-up were not statistically significant $\left(\mathrm{P} \chi^{2}: \mathrm{p}=0.717\right)($ Graph 1).

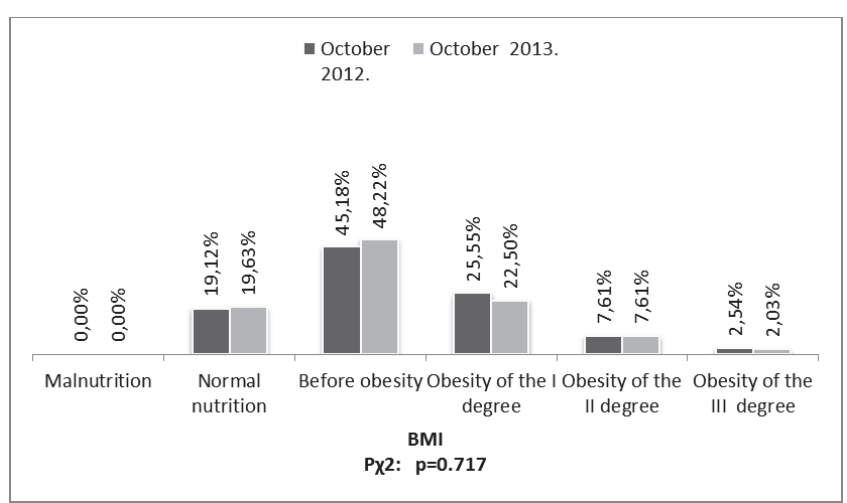

Graph 1. Presentation of the structure of participants according to BMI categories (\%)

Графикон 1. Структура испитаника (\%) према категоријама индекса телесне масе

At the beginning of the study 295 (49.92\%) of the participants had a proper diet, while at the end of the study number of patients who adhered advices on proper nutrition increased to 453 (76.65\%) (Graph 2). These changes during the study were statistically significant $(\mathrm{P} \chi 2: \mathrm{p}<0.001)$.

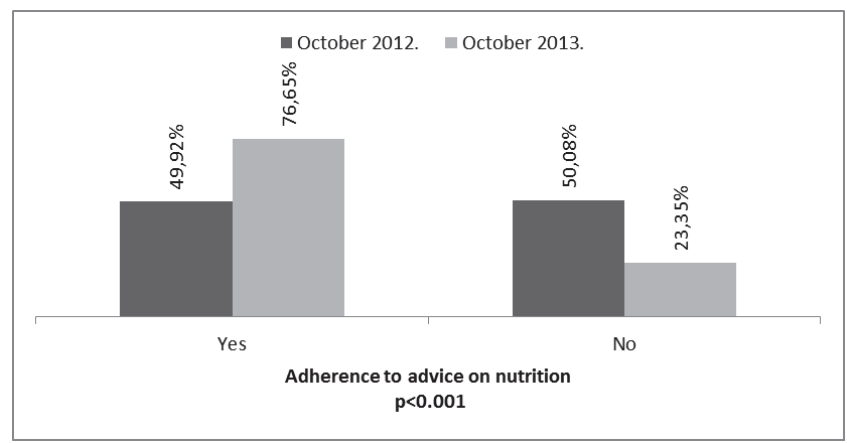

Graph 2. Respondents display in relation to advice on proper nutrition

Графикон 2. Придржавање савета о правилној исхрани

The highest values of $\mathrm{HbA}_{1} \mathrm{c}(>8.50 \%)$, at the beginning of the study, were recorded in a group of participants who did not adhere to advices $(67.76 \%)$. At the end of the study, the lowest $\mathrm{HbA}_{1} \mathrm{c}$ values $(\leq 6.50 \%)$ were present in the group of participants who have adhered to the advices (86.62\%). Adherence to advices during our study was statistically significant on the reduction in $\mathrm{HbA}_{1} \mathrm{c}\left(\mathrm{P}^{2}: \mathrm{p}<0.001\right)$ (Table 2).

Table 2. Level of glycated hemoglobin in correlation to adherence to advices about nutrition

Табела 2. Вредности гликозираног хемоглобина у корелацији са придржавањем савета о исхрани

\begin{tabular}{|c|c|c|c|c|c|c|c|c|c|c|}
\hline & \multirow{3}{*}{$\begin{array}{l}\text { Adherence } \\
\text { to advices on } \\
\text { nutrition }\end{array}$} & \multicolumn{8}{|c|}{ Glycated hemoglobin } & \multirow{3}{*}{ p } \\
\hline & & \multicolumn{2}{|c|}{$<6,50$} & \multicolumn{2}{|c|}{$6,51-7,00$} & \multicolumn{2}{|c|}{$7,01-8,50$} & \multicolumn{2}{|c|}{$>8,50$} & \\
\hline & & $\mathrm{n}$ & $\%$ & $\mathrm{n}$ & $\%$ & $\mathrm{n}$ & $\%$ & $\mathrm{n}$ & $\%$ & \\
\hline \multirow{3}{*}{$\begin{array}{l}\text { October } \\
2012 .\end{array}$} & Yes & 58 & 61,70 & 71 & 58,20 & 117 & 52,47 & 49 & 32,24 & \multirow{3}{*}{$<0.001$} \\
\hline & No & 36 & 38,30 & 51 & 41,80 & 106 & 47,53 & 103 & 67,76 & \\
\hline & Total & 94 & & 122 & & 223 & & 152 & & \\
\hline \multirow{2}{*}{$\begin{array}{l}\text { October } \\
2013 \text {. }\end{array}$} & No & 40 & 13,38 & 38 & 25,68 & 59 & 42,45 & 1 & 20,00 & \multirow[b]{2}{*}{$<0.001$} \\
\hline & $\begin{array}{l}\text { Total } \\
\text { Yes }\end{array}$ & $\begin{array}{l}299 \\
259\end{array}$ & 86,62 & $\begin{array}{l}148 \\
110\end{array}$ & 74,32 & $\begin{array}{l}139 \\
80\end{array}$ & 57,55 & $\begin{array}{l}5 \\
4\end{array}$ & 80,00 & \\
\hline
\end{tabular}

Among patients who adhered to advices on healthy eating, percentage of those with blood pressure of 130/80 $\mathrm{mm} \mathrm{Hg}$ and lower was significantly higher than with blood pressure above $130 / 80 \mathrm{mmHg}$ (Table 3).

Table 3. Correlation of adherence to dietary advices and the values of blood pressure in type 2 diabetes

Табела 3. Корелација између придржавања савета о исхрани и вредности крвног притиска код дијабетеса тип 2

\begin{tabular}{|c|c|c|c|c|c|c|}
\hline & \multirow{3}{*}{$\begin{array}{l}\text { Adherence } \\
\text { to advice on } \\
\text { nutrition }\end{array}$} & \multicolumn{4}{|c|}{ Blood pressure } & \multirow[t]{3}{*}{$\mathbf{p}$} \\
\hline & & \multicolumn{2}{|c|}{$>130 / 80$} & \multirow{2}{*}{\multicolumn{2}{|c|}{$\begin{array}{l}\leq 130 / 80 \\
\%\end{array}$}} & \\
\hline & & $\%$ & $\mathrm{n}$ & & & \\
\hline \multirow{3}{*}{$\begin{array}{l}\text { October } \\
2012 .\end{array}$} & Yes & 132 & 43,85 & 163 & 56,21 & \multirow[t]{3}{*}{0.003} \\
\hline & No & 169 & 56,15 & 127 & 43,79 & \\
\hline & Total & 301 & & 290 & & \\
\hline \multirow{2}{*}{$\begin{array}{l}\text { October } \\
2013 .\end{array}$} & Yes & 107 & 67,72 & 346 & 79,91 & \multirow[t]{2}{*}{0.002} \\
\hline & $\begin{array}{l}\text { No } \\
\text { Total }\end{array}$ & $\begin{array}{l}51 \\
158\end{array}$ & 32,28 & $\begin{array}{l}87 \\
433\end{array}$ & 20,09 & \\
\hline
\end{tabular}


Level of total cholesterol in the participants who did not adhere to advice about healthy eating was increased. This difference is statistically significant both in October $2012\left(\mathrm{P} \chi^{2}\right.$ : $\mathrm{p}=0.049)$ and in October $2013\left(\mathrm{P} \chi^{2}: \mathrm{p}=0.003\right)$. At the end of the study, the highest percentage of participants $(82.14 \%)$ who did adhere to dietary advice, had LDL cholesterol values ranging from 1.80 to $2.59 \mathrm{mmol} / \mathrm{l}$, which is statistically significant $\left(\mathrm{P} \chi^{2}: \mathrm{p}=0.001\right)$ (Table 4$)$.

Table 4. Correlation of compliance with advice on nutrition and level of total and LDL cholesterol

Табела 4. Корелација између придржавања савета о исхрани и вредности укупног и $L D L$ холестерола

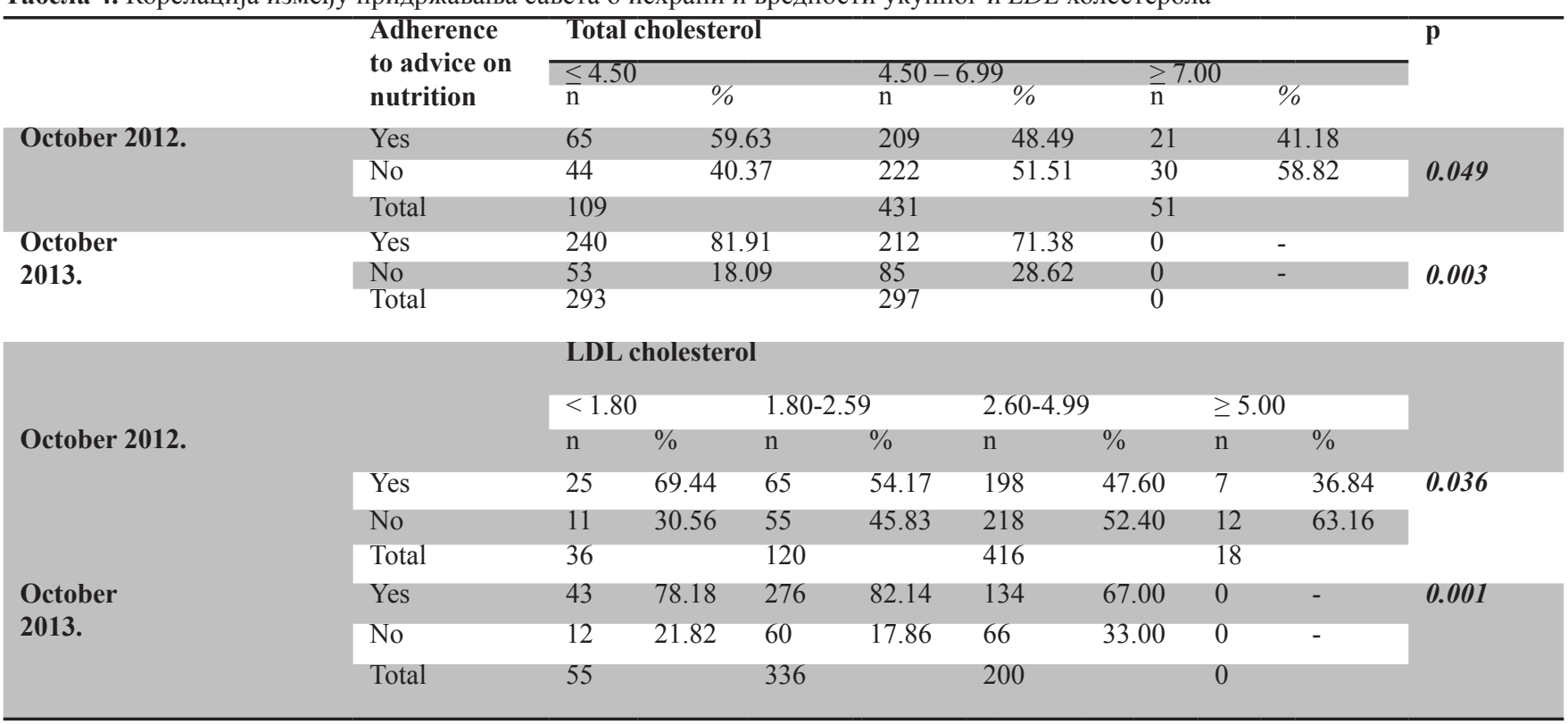

At the beginning of the study $116(19.63 \%)$ of participants did not have any physical activity, while at the end of the study the number of participants who did not have any physical activity was reduced to $20(3.38 \%)$. Also, the increase in the percentage of participants who were engaged in physical activity 3 to 5 times per week was recorded (Graph 3 ). Increasing of physical activity in patients during 13 month study was statistically significant $\left(\mathrm{P} \chi^{2}: \mathrm{p}<0.001\right)$.

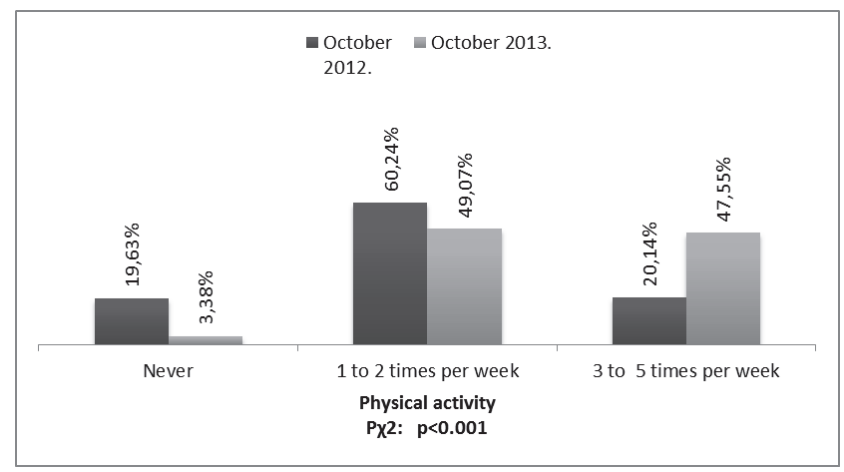

Graph 3. Physical activity in participants

Графикон 3. Физичка активност испитаника
Impact of physical activity on $\mathrm{HbA}_{1} \mathrm{c}$ values in our study is shown in Table 5. The highest values of $\mathrm{HbA}_{1} \mathrm{c}(>8.50 \%)$ at the beginning of the study were recorded in the group of subjects who 'never' engaged in physical activity $(28.95 \%)$. At the end of the study, the lowest HbAlc values $(\leq 6.50 \%)$ were present in the group of subjects who practiced physical activity 3 to 5 times per week (58.53\%). Impact of Increased physical activity on decrease of the $\mathrm{HbA}_{1} \mathrm{c}$ level during the 13 -month study, was statistically significant $\left(\mathrm{P} \chi^{2}: \mathrm{p}<0.001\right)$. 
Table 5. Correlation between physical activity and level of glycosylated hemoglobin

Табела 5. Корелација између физичке активности и нивоа гликозилираног хемоглобина

\begin{tabular}{|c|c|c|c|c|c|c|c|c|c|c|}
\hline & \multirow{3}{*}{$\begin{array}{l}\text { Physical } \\
\text { activity }\end{array}$} & \multicolumn{8}{|c|}{ Glycated hemoglobin } & \multirow[t]{3}{*}{$\mathbf{p}$} \\
\hline & & \multicolumn{2}{|l|}{$\leq 6,50$} & \multicolumn{2}{|c|}{$6,51-7,00$} & \multicolumn{2}{|c|}{$7,01-8,50$} & \multicolumn{2}{|c|}{$\geq 8,50$} & \\
\hline & & $\mathrm{n}$ & $\%$ & $\mathrm{n}$ & $\%$ & $\mathrm{n}$ & $\%$ & $\mathrm{n}$ & $\%$ & \\
\hline \multirow{4}{*}{$\begin{array}{l}\text { O c t o b e r } \\
2012 .\end{array}$} & Never & 15 & 15,96 & 14 & 11,48 & 43 & 19,28 & 44 & 28,95 & $<0.001$ \\
\hline & $\begin{array}{l}1 \text { to } 2 \text { times per } \\
\text { week }\end{array}$ & 48 & 51,06 & 71 & 58,20 & 139 & 62,33 & 98 & 64,47 & \multirow{7}{*}{$<0.001$} \\
\hline & $\begin{array}{l}3 \text { to } 5 \text { times per } \\
\text { week }\end{array}$ & 31 & 32,98 & 37 & 30,33 & 41 & 18,39 & 10 & 6,58 & \\
\hline & Total & 94 & & 122 & & 223 & & 15 & & \\
\hline \multirow{4}{*}{$\begin{array}{l}\text { October } \\
2013 .\end{array}$} & Never & 6 & 2,01 & 4 & 2,70 & 10 & 7,19 & 0 & 0,00 & \\
\hline & $\begin{array}{l}1 \text { to } 2 \text { times per } \\
\text { week }\end{array}$ & 118 & 39,46 & 79 & 53,38 & 90 & 64,75 & 3 & 60,00 & \\
\hline & $\begin{array}{l}3 \text { to } 5 \text { times per } \\
\text { week }\end{array}$ & 175 & 58,53 & 65 & 43,92 & 39 & 28,06 & 2 & 40,00 & \\
\hline & Total & 299 & & 148 & & 139 & & 5 & & \\
\hline
\end{tabular}

In the group of subjects who were not physically active, at the beginning of the study, elevated blood pressure $(>130 / 80 \mathrm{mmHg})$ was present at 65 subjects $(21.59 \%)$. At the end of the study, blood pressure values of $\leq 130 / 80 \mathrm{mmHg}$ were the most frequent in the group of subjects who applied 3 to 5 times per week physical activity $(53.58 \%)$. The difference was statistically significant both in October 2012 and in October 2013 (Table 6).

Table 6. Correlation between physical activity and blood pressure

Табела 6. Корелација између физичке активност и крвног притиска

\begin{tabular}{|c|c|c|c|c|c|c|}
\hline & \multirow{3}{*}{$\begin{array}{l}\text { Physical } \\
\text { activity }\end{array}$} & \multicolumn{4}{|c|}{ Blood pressure - diabetes } & \multirow[t]{3}{*}{$\mathbf{p}$} \\
\hline & & \multicolumn{2}{|c|}{$>130 / 80$} & \multicolumn{2}{|c|}{$\leq 130 / 80$} & \\
\hline & & $\mathrm{n}$ & $\%$ & $\mathrm{n}$ & $\%$ & \\
\hline \multirow{3}{*}{$\begin{array}{l}\text { October } \\
2012 .\end{array}$} & Never & 65 & 21,59 & 51 & 17,59 & \multirow[t]{5}{*}{$<0.001$} \\
\hline & $\begin{array}{l}1 \text { to } 2 \text { times per } \\
\text { week }\end{array}$ & 201 & 66,78 & 155 & 53,45 & \\
\hline & 3 to 5 times per & 35 & 11,63 & 84 & 28,97 & \\
\hline \multirow{5}{*}{$\begin{array}{l}\text { October } \\
2013 \text {. }\end{array}$} & $\begin{array}{l}\text { week } \\
\text { Total }\end{array}$ & 301 & & 290 & & \\
\hline & Never & 6 & 3,80 & 14 & 3,23 & \\
\hline & 1 to 2 times per & 103 & 65,19 & 187 & 43,19 & \multirow{3}{*}{$<0.001$} \\
\hline & $\begin{array}{l}\text { week } \\
3 \text { to } 5 \text { times per } \\
\text { week }\end{array}$ & 49 & 31,01 & 232 & 53,58 & \\
\hline & Total & 158 & & 433 & & \\
\hline
\end{tabular}

At the beginning of the study, no statistically significant influence of physical activity on the reduction of total and LDL cholesterol levels was observed. During the 13 months of physical activity, more than half of the participants who practiced physical activity 3 to 5 times per week had a total cholesterol level $<4.50 \mathrm{mmol} / \mathrm{L}(54.61 \%)\left(\mathrm{P} \chi^{2}: \mathrm{p}=0.003\right)$ and LDL Cholesterol level $<1.80 \mathrm{mmol} / \mathrm{L}$ (50.91\%) (P $\left.\chi^{2}: \mathrm{p} 0.028\right)$ (Table 7). 
Table 7. Influence of physical activity on level of total and LDL cholesterol at the beginning and at the end of the study Табела 7. Корелација између физичке активности и нивоа укупног и $L D L$ холестерола на почетку и на крају студије

\begin{tabular}{|c|c|c|c|c|c|c|c|c|c|c|}
\hline & \multirow{3}{*}{ Physical activity } & \multicolumn{8}{|c|}{ Total cholesterol } & \multirow[t]{3}{*}{$\mathbf{p}$} \\
\hline & & \multicolumn{3}{|c|}{$\leq 4,50$} & \multicolumn{3}{|c|}{$4,50-6,99$} & \multicolumn{2}{|c|}{$\geq 7,00$} & \\
\hline & & $\mathrm{n}$ & o & & $\mathrm{n}$ & & & $\mathrm{n}$ & $\%$ & \\
\hline \multirow{4}{*}{$\begin{array}{l}\text { October } \\
2012 \text {. }\end{array}$} & Never & 23 & & & 86 & & 95 & 7 & 13,73 & \multirow[t]{4}{*}{0.051} \\
\hline & 1 to 2 times per & 57 & & & 260 & & 32 & 39 & 76,47 & \\
\hline & $\begin{array}{l}\text { week } \\
3 \text { to } 5 \text { times per } \\
\text { week }\end{array}$ & 29 & & & 85 & & 72 & 5 & 9,80 & \\
\hline & $\begin{array}{l}\text { Total } \\
\text { Never }\end{array}$ & 109 & & & $\begin{array}{l}431 \\
13\end{array}$ & & & 51 & - & \\
\hline \multirow{5}{*}{$\begin{array}{l}\text { October } \\
2013 .\end{array}$} & 1 to 2 times per & 126 & & & 163 & & 88 & 0 & - & \multirow[t]{3}{*}{0.003} \\
\hline & $\begin{array}{l}\text { week } \\
3 \text { to } 5 \text { times per }\end{array}$ & 160 & & & 121 & & 74 & 0 & - & \\
\hline & $\begin{array}{l}\text { week } \\
\text { Total }\end{array}$ & 293 & & & 297 & & & 0 & & \\
\hline & & \multicolumn{8}{|c|}{ LDL cholesterol } & \\
\hline & & \multicolumn{2}{|c|}{$<1.80$} & \multicolumn{2}{|c|}{$1.80-2.59$} & \multicolumn{2}{|c|}{$2.60-4.99$} & \multicolumn{2}{|c|}{$\geq 5.00$} & \multirow{5}{*}{0.817} \\
\hline \multirow{5}{*}{$\begin{array}{l}\text { October } \\
2012 \text {. }\end{array}$} & Never & $\begin{array}{l}n \\
6\end{array}$ & $\begin{array}{l}\% \\
16.67\end{array}$ & ${ }_{21}^{n}$ & $\begin{array}{l}\% \\
17.50\end{array}$ & $\begin{array}{l}n \\
84\end{array}$ & 20.19 & $\frac{n}{5}$ & 26.32 & \\
\hline & 1 to 2 times per & 24 & 66.67 & 76 & 63.63 & 244 & 58.65 & 12 & 63.16 & \\
\hline & $\begin{array}{l}\text { week } \\
3 \text { to } 5 \text { times per }\end{array}$ & 6 & 16.67 & 23 & 19.17 & 88 & 21.15 & 2 & 10.53 & \\
\hline & $\begin{array}{l}\text { week } \\
\text { Total }\end{array}$ & 36 & & 120 & & 416 & & 19 & & \\
\hline & Never & 2 & 3.64 & 12 & 3.57 & 6 & 3.00 & 0 & - & \multirow{4}{*}{0.028} \\
\hline \multirow{3}{*}{$\begin{array}{l}\text { October } \\
2013 \text {. }\end{array}$} & 1 to 2 times per & 25 & 45.45 & 148 & 44.05 & 117 & 58.50 & 0 & - & \\
\hline & $\begin{array}{l}\text { week } \\
3 \text { to } 5 \text { times per }\end{array}$ & 28 & 50.91 & 176 & 52.38 & 77 & 38.50 & 0 & - & \\
\hline & $\begin{array}{l}\text { week } \\
\text { Total }\end{array}$ & 55 & & 336 & & 200 & & 0 & & \\
\hline
\end{tabular}

\section{Discussion}

By applying the recommendations of lifestyle change at the end of the 13 months of our study, the highest percentage $(54.84 \%)$ of male patients achieved the ideal values of HbA1c $(<6.50 \%)$, while percentage in women was slightly lower $(45.91 \%)\left(\mathrm{P} \chi^{2}: \mathrm{p}=0.001\right)$. The results of a multicentric oneyear study, conducted on 5,000 subjects, obese patients with type 2 diabetes, indicated that the application of educational programs on intensive lifestyle changes (the correct diet and individually adapted and regular physical activity) leads to a significant reduction in body weight (by 8.60\%) and better glycemic control [reduction of HbAlc from $7.30 \%$ to $6.60 \%$ $(\mathrm{p}<0.001)]$, but also the reduction of all cardiovascular risk factors $(\mathrm{p}<0.001)^{23}$.

At the beginning of our study (October 2012), 49.92\% of participants practiced the correct diet recommendations (low caloric index food, the number of daily meals and the recommended daily salt intake), and at the end of the study (October 2013) their percentage was 76.65\% $(\mathrm{P} \chi 2: \mathrm{p}=0.001)$. Reduction in body weight was the most pronounced in subjects with first degree obesity, whose percentage decreased from 25.55\% (October 2012) to 22.50\% (October 2013) (P $\chi^{2}$ : $\mathrm{p}=0.717)$. At the beginning of the study, the highest percentage of participants who did not adhere to advice on nutrition $(67.76 \%)$ had $\mathrm{HbA} 1 \mathrm{c}>8.50 \%$, while at the end of the study the highest percentage of participants who adhered to the advice on nutrition $(86.62 \%)$ achieved ideal values of $\mathrm{HbA} 1 \mathrm{c}$ $(<6.50 \%)\left(\mathrm{P} \chi^{2}: \mathrm{p}=0.001\right)$. Shai and associates, during their research, followed three dietary regimes: a low-carb intake diet, a Mediterranean diet, and a low-fat diet, in 322 moderately obese subjects with diabetes, for a period of two years. Their research has shown that Mediterranean nutrition significantly improves glycemic load and prevents the onset of insulin resistance ${ }^{24}$. At the start of the study, $163(56.21 \%)$ of the participants who adhered to advices on nutrition had blood pressure of $130 / 80 \mathrm{mmHg}$ or lower at the start of the study $(\mathrm{P} \chi 2: \mathrm{p}=0.003)$, and at the end of the study percentage was higher $346(79.91 \%)(\mathrm{P} \chi 2: \mathrm{p}=0.002)$.

The recommended level of total cholesterol $(\leq 4.5$ $\mathrm{mmol} / \mathrm{L})$ was present at 65 subjects $(59.63 \%)$ at the start of the study, and at the end $240(81.91 \%)$, while the recommended level of LDL cholesterol $(<1.80 \mathrm{mmol} / \mathrm{L})$ was measured in $(69.44 \%)$ of participants, and finally at 43 participants $(78.18 \%)$. 
In Steno-2 Study of patients with type 2 diabetes on multi-intensive therapy, the level of $\mathrm{HbA} 1 \mathrm{c}$ below $6.5 \%$ was achieved in $15 \%$ of cases, while the total cholesterol level below $4.5 \mathrm{mmol} / \mathrm{L}$ and diastolic blood pressure below 80 $\mathrm{mmHg}$, were achieved in $70 \%$ of cases. The study used combined therapeutic options and individually tailored programs to reduce cardiovascular risk factors, as well as motivation groups with the participation and support of spouses.

All of this required the empowerment of the role of doctors of the primary health care level and the application of educational and motivational processes. In the study, it is emphasized that intensive treatment of cardiovascular risk factors in patients with type 2 diabetes significantly reduces the rate of cardiovascular complications ${ }^{25}$.

At the beginning of the study, 44 (28.95\%) of subjects who had never used physical activity had the highest values of $\mathrm{HbA}_{1} \mathrm{c}(>8.50 \%)$. Physical activity 3 to 5 times per week at the beginning of the study practiced $20.14 \%$ of subjects, and at the end $47.55 \%$ of subjects. In this group of patients percentage $(58.53 \%)$ of the ideal $\mathrm{HbA}_{1} \mathrm{c}$ values $(<6.50 \%)$ was the highest. Conducting intense physical activity that involves demanding exercises (three series of exercises, three times a week) in patients with diabetes leads to a significant reduction in $\mathrm{HbA}_{1} \mathrm{c}$ by $1.1-1.2 \%$, and to the reduction of complications of diabetes ${ }^{26}$.

At the beginning of the study, 155 (53.45\%) participants who applied physical activity 1 to 2 times per week, had a blood pressure of $130 / 80 \mathrm{mmHg}$ or lower, and at the end of the study, blood pressure of $130 / 80 \mathrm{~mm} \mathrm{Hg}$ was found in $232(53.58 \%)\left(\mathrm{P} \chi^{2}: \mathrm{p}<0.001\right)$ of the participants who had physical activity 3 to 5 times per week. The recommended level of total cholesterol $(\leq 4.5 \mathrm{mmol} / \mathrm{L})$ was present in 57 (52.29\%) of participants who applied physical activity 1 to 2 times per week at the beginning of the study, and at the end, $160(54.61 \%)$ of participants who applied physical activity 3 to 5 times per week had recommended level of total cholesterol, while the recommended level of LDL cholesterol $(<1.80 \mathrm{mmol} / \mathrm{L})$ at the beginning of the study was present in $24(66.67 \%)$ of the subjects who had a physical activity 1 to 2 times a week and at the end of the study in $28(50.91 \%)$ of subjects who had physical activity " 3 to 5 times per week" $(\mathrm{P} \chi 2: \mathrm{p}<0.028)$

\section{Conclusion}

During our research, continuous and individual counseling of type 2 diabetes patients on the use of proper nutrition and engaging in regular physical activity led to a decrease in $\mathrm{HbAlc}$, blood pressure, and lipids. Recommendations on changing of the lifestyle need to be adjusted individually and brought in accordance with the patient with diabetes, taking into account. 
Сузана Савић $\hbar^{1,3}$, Гордана Тешановић ${ }^{1,3}$,

Косана Станетић ${ }^{1,3}$,

Снјежана Поповић-Пејичић $\hbar^{2,3}$

'Дом здравља Бања Лука,

${ }^{2}$ Унивезитетски клинички центар Бања Лука,

${ }^{3}$ Медицински факултет, Универзитет у Бањој Луци,

Република Српска, Босна и Херзеговина
Утицај промена начина живота на параметре контроле гликемије пацијената са дијабетесом тип 2

\section{Сажетак}

Увод. Промјена стила живота (правилна исхрана, физичка активност) могу значајно утицати на постизање добре гликорегулације, циљних вриједности крвног притиска и параметара из липидног статуса.

Циљ рада. Утврдити постизање циљних вриједности гликозилираног хемоглобина $\left(H b A_{l} c\right)$, крвног притиска и липида код испитаника са дијабетесом тип 2 , који су примјењивали правилну исхрану и контролисану физичку активност.

Метод. Истраживање је проспективна студија, провођена у 60 тимова породичне медицине на испитаницима са дијабетесом тип 2, од 01. октобра 2012. до 31. октобра 2013, у Дому здравља Бања Лука. Сви испитаници су на почетку студије имали индивидуално савјетовање о исхрани, физичкој активности и прекиду пушења.

Резултати. Истраживањем је обухваћен 591 испитаник са дијабетесом тип 2. Правилан начин исхране на почетку студије примјењивало је $49,92 \%$, а на крају студије $76.65 \%$ испитаника $\left(P \chi^{2}: p<0,001\right)$. Циљну вриједност $H b A_{l} c$ $\leq 6,5 \%$ на почетку студије постигло је $61,70 \%$, а на крају студије $86,62 \%$ ( $P \chi^{2}$ : $p<0,001)$; циљну вриједност крвног притиска $(\leq 130 / 80 \mathrm{mmHg})$ постигло је на почетку студије $56,21 \%$, а на крају студије $79,91 \%$ ( $\left.P \chi^{2}: p<0.002\right)$; циљну вриједност укупног холестерола на почетку студије постигло је 59,61\%, а на крају студије $81,91 \%\left(P \chi^{2}: p<0,003\right)$.

Закључак. Индивидуално савјетовање обољелих од дијабетеса тип 2 о промјени начина живота, помаже у постизању оптималне вриједности $H b A_{l} c$, крвног притиска и липида. 


\section{References}

\section{Литература}

1. Popović-Pejičić S. Prevencija i kontrola dijabetesa. U: Vulić D, Babić NV, urednici. Hronične nezarazne bolesti. Banja Luka: Narodna i univerzitetska biblioteka Republike Srpske; 2011. str.159-74.

2. Savić S. Efekti primjene kliničkog vodiča u liječenju pacijenata sa dijabetes melitusom tip 2 [doktorska disertacija]. Banja Luka (RS): Medicinski fakultet, Univezitet u Banjoj Luci, 2016.

3. Tešanović G, i sar. Porodična medicina. Banja Luka: Medicinski fakultet, Narodna i univerzitetska biblioteka Republike Srpske, 2014.

4. Stanetić K. Prevencija u radu porodičnog ljekara. Banja Luka: Medicinski fakultet, Narodna i univerzitetska biblioteka Republike Srpske, 2015.

5. Haas L, Maryniuk M, Beck J, et al. National Standards for Diabetes SelfManagement Education and Support. Diabetes Care 2014; 37 Suppl 1: S144-S53.

6. Anderson JW, Kendall CW, Jenkins DJ. Importance of weight management in type 2 diabetes: review with metaanalysis of clinical studies. J Am Coll Nutr 2003;22:331-9.

7. Dagenais GR, Yi Q, Mann JF, Bosch J, Pogue J, Yusuf S. Prognostic impact of body weight and abdominal obesity in women and men with cardiovascular disease. Am Heart J 2005;149(1):54-60.

8. Keymel S, Heinen Y, Balzer J, Rassaf $\mathrm{T}$, et al. Characterization of macro- and microvascular function and structure in patients with type 2 diabetes mellitus. Am J Cardiovasc Dis 2011;1(1): 68-75.

9. Boulé NG, Haddad E, Kenny GP, Wells GA, Sigal RJ. Effects of exercise on glycemic control and body mass in type 2 diabetes mellitus: a meta-analysis of controlled clinical trials. JAMA 2001;286:1218-27.

10. Vrca Botica M, Pavlić-Rena I i sar. Šećerna bolest u odraslih. Zagreb: Školska knjiga; 2012.Stephan FE, Luc JC. Exercise therapy in Type 2 diabetes. Acta Diabetol 2009;46:263-78.

11. Stephan FE, Luc JC. Exercise therapy in Type 2 diabetes. Acta Diabetol 2009;46: 263-78.
12. American Diabetes Association. Standards of Medical Care in Diabetes - 2016. Foundations of Care and Comprehensive Medical Evaluation. Diabetes Care 2016; 39 Suppl 1: S23-S35. Available from: http://care.diabetesjournals.org/site/ misc/2016-Standards-of-Care.pdf

13. Umpierre D, Ribeiro PAB, Kramer CK, Leitão CB, et al. Physical Activity Advice Only or Structured Exercise Training and Association with $\mathrm{HbA}_{1} \mathrm{c}$ Levels in Type 2 Diabetes. JAMA 2011; 305(17):1790-9.

14. Pejičić-Popović S, Stojisavljević-Šatara $\mathrm{S}$, Tešanović G, Bukara-Radujković B, Stanetić K, Vuković B. Bolesti žlijezda sa unutrašnjim lučenjem, ishrane $i$ metabolizma - Dijabetes melitus, Vodič za kliničku praksu. Banja Luka, Ministarstvo zdravlja i socijalne zaštite Republike Srpske; 2010.

15. American Diabetes Association. Standards of Medical Care in Diabetes - 2016. Foundations of Care and Comprehensive Medical Evaluation. Diabetes Care 2016; 39 Suppl 1: S23-S35. Available from: http://care.diabetesjournals.org/site/ misc/2016-Standards-of-Care.pdf

16. American Diabetes Association. Standards of Medical Care in Diabetes 2012. Position statement. Diabetes Care 2012; 35 Suppl 1: S11-S63.

17. American Diabetes Association. Standards of Medical Care in Diabetes 2013. Position statement. Diabetes Care 2013; 36 Suppl 1: S11-S66.

18. Inzucchi SE, Bergenstal R, Buse JB, et al. Management of hyperglycemia in type 2 diabetes: a patient-centered approach. Position statement of the American Diabetes Association (ADA) and European Association for the Study of Diabetes (EASD). Diabetes Care 2012;35:1364-79.

19. American Diabetes Association. Standards of Medical Care in Diabetes - 2015. Diabetes Care 2015; 38 Suppl 1: S49-S57.

20. Lalić MN, Zamklar M, Pudar G, Kocić R, Antić S, Pešić M, i sar. Nacionalni vodič kliničke prakse za dijagnostikovanje i lečenje dijabetes melitusa.

Republička stručna komisija za izradu i implementaciju Vodiča dobre kliničke prakse. Beograd: Ministrastvo zdravlja Republike Srbije; 2012.
21. Fond zdravstvenog osiguranja Republike Srpske. Stručno uputstvo za otkrivanje $i$ redukciju rizičnih faktora i rano otkrivanje oboljenja iz Programa prevencije $i$ kontrole nezaraznih bolesti u Republici Srpskoj i Institut za zaštitu zdravlja Republike Srpske. Banja Luka: FZO RS; 2003.

22. Kvaternik M, Perone SA, Perone N. Vodič za odvikavanje od pušenja. Banja Luka/Doboj: Institut za zaštitu zdravlja Republike Srpske; 2006.

23. Look AHEAD Research Group. Reduction in weight and cardiovascular disease risk factors in individuáis with type 2 diabetes: one-year results of the Look AHEAD trial. Diabetes Care 2007; 30(6):1374-83.

24. Shai I, Schwarzfuchs D, Henkin Y, et al. Dietary Intervention Randomized Controlled Trial (DIRECT) Group. Weight loss with a low-carbohydrate. Mediterranean or low-fat diet. N Engl J Med 2008; 359(3): 229-41.

25. Rujiz J. Intensive care of type 2 diabetes: what does the STENO 2 study teach us. Rev Med Suisse Romande 2004; 124 (3): 125-7

26. Dunstan DW, Daly RM, Owen N, Jolley D, de Courten M, Shaw J, Zimett P. Highintensity resistance training improves glycemic control in older persons with type 2 diabetes. Diabetes Care 2002;25: 1729-35.

Primljen • Received: $\quad 21.06 .2017$. Ispravljen • Corrected: 20.12.2017. Prihvaćen • Accepted: $\quad 22.12 .2017$. 